\title{
Sentrin-Specific Protease 1
}

National Cancer Institute

\section{Source}

National Cancer Institute. Sentrin-Specific Protease 1. NCI Thesaurus. Code C98063.

Sentrin-specific protease 1 (644 aa, $73 \mathrm{kDa}$ ) is encoded by the human SENP1 gene. This protein is involved in both caspase activation and protein desumoylation. 